\title{
Clarithromycin as a steroid sparing agent for the management of infantile bullous pemphigoid
}

\author{
Simon Tso, ${ }_{1}^{1}$ Gabriela Petrof, ${ }^{2}$ Simon Unter, ${ }^{2}$ Frances Humphreys ${ }^{2}$
}

'Dermatology, University Hospitals Coventry and Warwickshire NHS Trust, Coventry, UK

${ }^{2}$ Jephson Dermatology Center, South Warwickshire NHS Foundation Trust, Warwick, UK

\section{Correspondence to}

Dr Simon Tso,

simontso@doctors.org.uk

Accepted 16 January 2018

\section{DESCRIPTION}

A 5-month-old woman presented with a 1-week history of a bullous eruption that started at acral sites and spread centrally. There was no preceding illness and she had taken no medications. Her last vaccination was at 3 months old per UK immunisation schedule. On examination, her temperature was $38^{\circ} \mathrm{C}$ and weight was $7.6 \mathrm{~kg}$. She appeared well but had widespread intact and deroofed bullae with an erythematous base predominantly affecting acral sites with no mucosal involvement (figure 1). Investigations revealed an eosinophilia of $1.33 \times 10^{9} / \mathrm{L}$ with normal C-reactive protein. Viral PCR of blister fluid was negative for herpes simplex virus type 1 (HSV1), HSV2 and varicella-zoster virus. A skin biopsy showed a dense mixed inflammatory cell infiltrate in the papillary dermis. Direct immunofluorescence microscopy showed linear deposition of IgG and C3 along the basement membrane. Indirect immunofluorescence on salt split skin localised to the roof and ELISA demonstrated antibodies against bullous pemphigoid (BP)180 at $145 \mathrm{U} / \mathrm{mL}$ only. The patient was treated with oral flucloxacillin $(62.5 \mathrm{mg}$ four times a day; 1 week), oral prednisolone at $4 \mathrm{mg}$ once daily $(0.53 \mathrm{mg} / \mathrm{kg} / \mathrm{day})$, ranitidine $4 \mathrm{mg}$ three times daily, Dermol 500 lotion and topical Fucibet

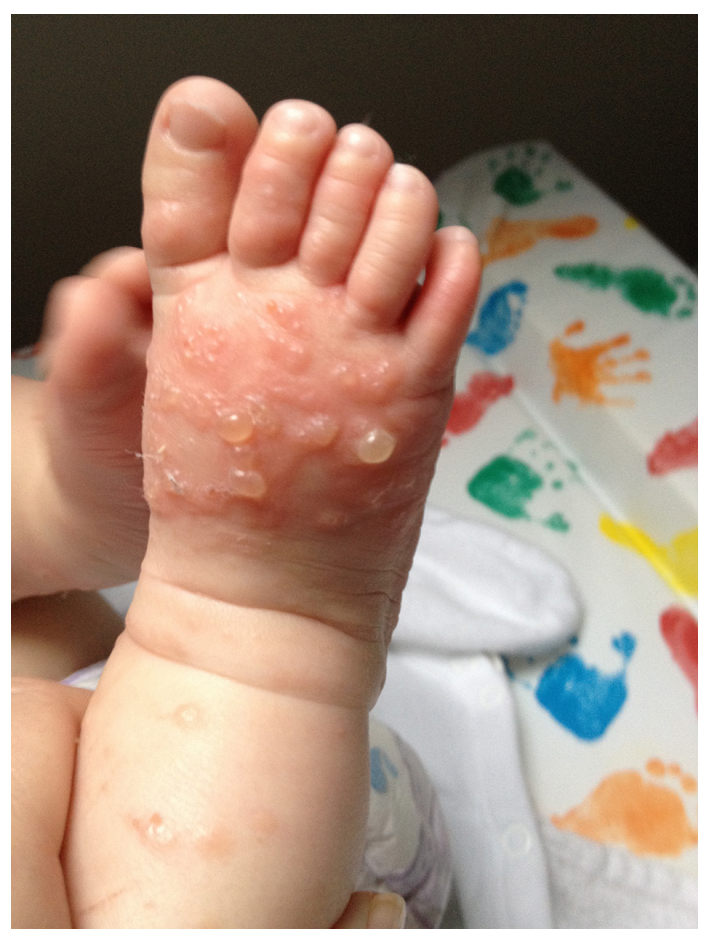

Figure 1 The patient's right foot with widespread intact bullae with an erythematous base. cream (fusidic acid 2\% and betamethasone 0.1\%) twice daily. Oral erythromycin $125 \mathrm{mg}$ twice daily was added 1 week later as a steroid sparing agent but was switched to clarithromycin $25 \mathrm{mg}$ twice daily (half of antimicrobial dose) due to 2 weeks of diarrhoea. By week 10, the infant's weight had increased to $8.33 \mathrm{~kg}$ (above 50th centile). Her oral prednisolone was gradually reduced to $1.5 \mathrm{mg}$ /day $(0.18 \mathrm{mg} / \mathrm{kg} / \mathrm{day})$, her clarithromycin dose increased to $75 \mathrm{mg}$ /day and the patient remained blister free since then (figure 2). Prednisolone was stopped completely at the age of 12 months and clarithromycin was discontinued 3 months later after completion of her 12-month immunisations, which were given separately at fortnightly intervals.

A literature review identified 88 cases of infants with BP (age range 6 weeks to 12 months). ${ }^{12}$ In $22 / 88(25 \%)$ cases a vaccination was given prior to (1 day to 1 month) the onset of a bullous eruption. Two cases reported a relapse following revaccination. ${ }^{1}$ Seventy-three out of 88 (82.9\%) cases were treated with systemic corticosteroids (prednisolone at $1-3 \mathrm{mg} / \mathrm{kg} / \mathrm{day}$, methylprednisolone at $0.5-3 \mathrm{mg} / \mathrm{kg} /$ day, betamethasone at $0.3-2 \mathrm{mg} /$ $\mathrm{kg} / \mathrm{day}$, deflazacort at $1-3 \mathrm{mg} / \mathrm{kg} / \mathrm{day})$. The main

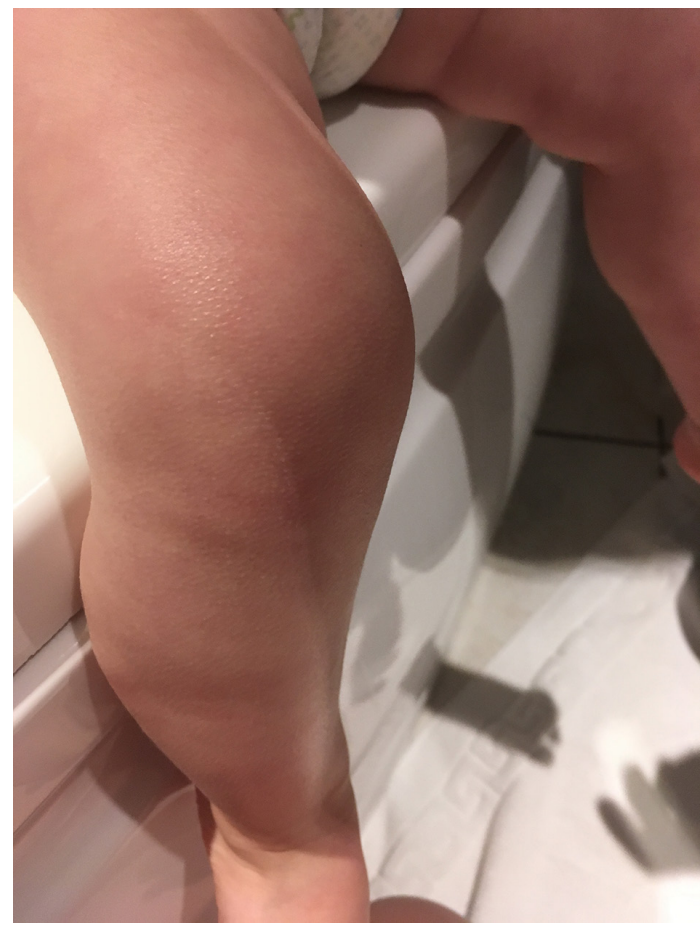

Figure 2 The patient's lower limbs 2 months after completion of all treatments with complete resolution of the bullous eruption. 
(Written by the mother)

- About a week before our daughter was admitted to hospital and diagnosed with childhood BP we took her to Accident and Emergency as we were concerned she had had some kind of severe allergic skin reaction (her skin was fine when we dressed her in the morning, but by evening bath time we noticed something was wrong.) The registrar we saw thought it was an allergic reaction, asked us to go \& buy Piriton and go to our GP if there were any further concerns. We took her back to our GP within a couple of days who diagnosed hand foot \& mouth, but without mouth ulcers. The printed-out guidelines for this disease described blisters so we weren't overly concerned to start with, but they kept getting bigger so we went back to the practice and were directed to go straight back to Accident and Emergency.

- At the time it was frustrating and upsetting that we had been there a week earlier and perhaps it could have been caught and treated sooner, but with hindsight knowing how rare this is in very young children I can understand the response of the busy registrar the week before.

- Once we saw the dermatology team on the ward I felt reassured and knew that they would reach a diagnosis and treat our little girl. It was clearly explained that a skin punch biopsy would be the most effective way to get an accurate diagnosis and so we consentedhad I ever seen the procedure before I may have been a little more worried about it, but I am pleased that the dermatology team was effective in his communication with us as it lead to a much quicker \& clearer diagnosis. Once we were discharged things continued to improve, with the odd set back in terms of new blisters forming, but we given clear guidelines about what to do in all eventualities. It was helpful that the long-term plan in terms of reducing her medication was shared with us. At nearly 18 months old now our daughter seems to have suffered no long-term effects from this disease.

- Although it was a harrowing time I am very grateful to the dermatology team who went over and above what I would have thought were his actual clinical duties to us, showing us great care, respect and was giving of his time. I think our experience and feelings about this event may have been very different were it not for their kind, but clearly evidence based approach.

steroid sparing agent used was dapsone (21/88 cases; $23.9 \%)$ at $0.5-2 \mathrm{mg} / \mathrm{kg} /$ day. Other steroid sparing agents used included erythromycin, intravenous immunoglobulins, sulfapyridine, mycophenolate mofetil, rituximab, nicotinamide, ciclosporin, azathioprine, cyclophosphamide and omalizumab.

Macrolides' mechanism of action on reducing inflammation in bullous dermatoses may include inhibition of the proinflammatory interleukin- 6 and interleukin- 8 cytokines and the inhibition of eosinophil recruitment. ${ }^{3}$ Prognosis of infantile BP is excellent

\section{Learning points}

- Positive bullous pemphigoid (BP)180 and negative BP230 are the usual findings in infants with $B P$, which may explain the better prognosis of $\mathrm{BP}$ in infants as compared with the elderly, as suggested recently by other authors. ${ }^{2}$

- There is no proven causal link between vaccination and the onset of infantile BP and we advocate that affected infants should continue with their routine immunisation schedule.

- Macrolides' non-antibiotic mechanism of action in reducing inflammation in bullous dermatoses makes it a useful steroid sparing treatment strategy in the treatment of infantile BP. although complete remission can vary from several weeks to several years. ${ }^{12}$ To the best of our knowledge, this is the first case report on the use of the macrolide antibiotic, clarithromycin, as a steroid sparing agent for the management of infantile BP.

Acknowledgements We thank Dr Fremlin, Dr Carr, Dr Gee, Dr Bedlow, Dr Carter, Dr Gach, Dr Ilchyshyn, Professor Mellerio and Dr Groves for their input into patient care.

Contributors ST was responsible for conception and design of the paper and drafted the initial manuscript. GP, SU and FH revised the manuscript critically for its important intellectual content. All authors approved the final version to be submitted and agreed to be accountable for the article.

Competing interests None declared.

Patient consent Guardian consent obtained.

Provenance and peer review Not commissioned; externally peer reviewed.

(c) BMJ Publishing Group Ltd (unless otherwise stated in the text of the article) 2018. All rights reserved. No commercial use is permitted unless otherwise expressly granted.

\section{REFERENCES}

1 Schwieger-Briel A, Moellmann C, Mattulat B, et al. Bullous pemphigoid in infants: characteristics, diagnosis and treatment. Orphanet J Rare Dis 2014;9:185.

2 Ferreira BR, Vaz AS, Ramos L, et al. Bullous pemphigoid of infancy - report and review of infantile and pediatric bullous pemphigoid. Dermatol Online J 2017;23.

3 Kanoh S, Rubin BK. Mechanisms of action and clinical application of macrolides as immunomodulatory medications. Clin Microbiol Rev 2010;23:590-615.

Copyright 2017 BMJ Publishing Group. All rights reserved. For permission to reuse any of this content visit

http://group.bmj.com/group/rights-licensing/permissions.

BMJ Case Report Fellows may re-use this article for personal use and teaching without any further permission.

Become a Fellow of BMJ Case Reports today and you can:

- Submit as many cases as you like

- Enjoy fast sympathetic peer review and rapid publication of accepted articles

- Access all the published articles

- Re-use any of the published material for personal use and teaching without further permission

For information on Institutional Fellowships contact consortiasales@bmjgroup.com

Visit casereports.bmj.com for more articles like this and to become a Fellow 